\title{
МОНОГРАМ - ГРАФИЧКИ ЗНАК ВЛАДАРСКОГ АУТОРИТЕТА НА СРПСКОМ СРЕДЊОВЕКОВНОМ НОВЦУ
}

\begin{abstract}
Сажетак
Пратећи појаву монограма на античком и средњовековном новцу Византије и Запада, те значај који је имао за владара и друштвене елите које су га користиле као репрезентативни графички знак идентитета, у раду се разматра порекло и значење монограма на српском средњовековном новцу. Он се у српском новчарству први пут појавио на динару Вука Бранковића, а потом ће га понети и новац деспота Стефана Лазаревића и Ђурђа Бранковића.

Кључне речи: монограм, новац, средњи век, Византија, Запад, Вук Бранковић, Деспотовина
\end{abstract}

Монограм је одувек био повезан са друштвеним елитама. У данашњем свету маркетинга, он се махом користи као лого, део визуелног идентитета компанија или појединаца, који је ту да остави утисак и допринесе стварању препознатљивог бренда. Циљ овог рада је да укаже да је и у средњовековном друштву међу владарима и припадницима вишег друштвеног сталежа, употреба монограма била статусни симбол који је садржио све визуелне аспекте и изражајност коју тражи данашњи свет комуникација.

Монограм настаје комбинацијом неколико слова која формирају знак, који постаје идентификациони знак одређене особе. Правилно прочитана, ова слова дају име, титулу (или име и титулу) власника монограма, а могу садржити и инвокацију. ${ }^{1}$ Прве монограме срећемо

1 W. Hörandner, Monogram, in: The Oxford Dictionary of Byzantium, Vol. III, A. P. Kazhdan (ed.), New York - Oxford 1991, 1397. 
већ на новцу који кују грчки градови-државе и ова пракса ће се наставити у хеленистичком периоду. ${ }^{2}$ У овом периоду, монограм најчешће означава ковницу из које новац потиче, а осим имена града и имена владара, на новцу се срећу и монограми магистрата, ковничара новца, па чак и самих гравера. У касноримском и рановизантијском периоду, монограм се чвршће везује за друштвене елите, постајући графички знак који се повезује са вишим друштвеним сталежом и ауторитетом. Као такав среће се на новцу, печатима, накиту, на капителима, мозаицима, у илуминираним рукописима итд.

Један од најзначајнијих монограма који настају у овом периоду је христограм. Појава христограма повезана је са визијом цара Константина Великог која се одиграла пре битке на Милвијском мосту, а Христов монограм биће први пут приказан на аверсу сребрне мултипле исковане у Тицинијуму 315. године, на шлему са којим је цар приказан. ${ }^{3}$ Издвојена слова Спаситељевог имена, исписаног на грчком $\mathrm{X}$ и P, укрштена у графичком знаку, постала су не само победнички знак самога цара, већ симбол хришћанске вере и божанског ауторитета, чији је визуелни идентитет остао аутентичан до данас.

Као знак царског ауторитета монограм је у Византији почео да се користи као реверсни тип бакарног новца од средине $\bigvee$ века, најчешће доносећи име владара у генитиву, те је посматран као signum владара. Први пут се појавио на бакарном новцу цара Теодосија II, кованом у Константинопољу и Никомедији, између 445. и 450. године. ${ }^{4}$ Овај затворени монограм, облика кутије, формиран око слова $\mathrm{H}$, X или 3, убрзо ће у време цара Јустиниана I, у последњим годинама његове владавине, око 560. године, заменити монограм у облику крста, на коме су слова била „закачена“ за кракове грчког крста,

2 V. Gardthausen, Das alte Monogramm, Wiesbaden 1924, 18-19; J. Spier, Late Antique and Early Medieval Gems, Wiesbaden 2007, 193; I. Garipzanov, The Rise of Graphicacy in Late Antiquity and the Early Middle Ages, Viator 46, No. 2 (2015), 1-21, 5.

3 A. Alföldi, The Helmet of Constantine with the Christian Monogram, The Journal of Roman Studies, Vol. 22, Part 1 (1932) 9-23, 10-11; P. Bruun, The Christian Signs on the Coins of Constantine, Arctos, n. S., 3 (1962) 5-35, 19, 24; isti, The Roman Imperial Coinage, Vol. VII, Constantine and Licinius: A. D. 313-337, London 1966, 61, 364, PI. 9, no. 36; I. Garipzanov, n. d., 6-7.

4 P. Grierson, Catalogue of the Byzantine Coins in the Dumbarton Oaks Collection and in the Whittemore Collection, Vol. 2, Pt. 1, Phocas and Heraclius (602-641), Washington 1968, 107-108. 
који ће постати типичан византијски монограм. ${ }^{5}$ У овом периоду монограм владара најчешће је био састављен од слова његовог имена, а један цар могао је имати више различитих типова монограма које је носио његов новац и печати. ${ }^{6}$ Осим цара, монограм су у Византији на својим печатима користили и представници државне и црквене администрације. ${ }^{7}$ Иако стално присутан у византијском новчарству, ${ }^{8}$ снажнија заступљеност и популарност монограма на новцу, после раносредњовековног периода, бележи се тек у време Палеолога, последње византијске династије.

На Западу, монограм се први пут појављује на бакарном новцу Либија Севера (461-465) искованом у Риму, а потом га германски владари, као краљевски монограм, стављају на свој сребрни новац. За разлику од византијског, латински монограм доноси име владара у генитиву или номинативу. Први краљевски монограм, на Западу, понео је сребрни новац Одоакара, искован у Равени. ${ }^{9}$ Ради се о затвореном типу монограма који опонаша монограм са новца Теодосија II. После доласка Острогота у Италију, монограм постаје уобичајан на њиховом сребрном новцу, а традиција коришћења монограма на новцу је, путем њих, пренета преко Алпа. Као потпис владара срећемо га у владарским повељама Меровинга које потичу из прве половине VII столећа, ${ }^{10}$ а касније ће се појавити и на новцу ${ }^{11}$ Новина коју доно-

5 Isto, 107-109, PI. II; P. Grierson, Byzantine Coins, London 1982, 33.

6 G. Zacos, A. Veglery, Byzantine Lead Seals I, Plates, Basel 1972, no. 2, 2b; P. Grierson, Byzantine Coins, 33; W. Seibt, The Use of Monograms on Byzantine Seals in the Early Middle-Ages, Parekbolai 6 (2016) 1-14, 4, fig. 3.

7 W. Seibt, n. d., 6-10.

8 P. Grierson, Catalogue II/1, 109; isti, Byzantine Coins, 188; isti, Catalogue of the Byzantine Coins in the Dumbarton Oaks Collection and in the Whittemore Collection, Vol. 3, Pt. 1, Leo III to Michael III (717-867), Washington 1973, 189-190.

9 J. P. C. Kent, The Roman Imperial Coinage, Vol. 10, The Divided Empire and the Fall of the Western Parts, A.D. 395-491, R. A. G. Carson, J. P. C. Kent, A. M. Burnett (eds.), London 1994, 60, 93, 277, no. 462-5, 408, no. 2715-7, 442, no 3501; M. A. Metlich, The Coinage of Ostrogothic Italy, London 2004, 123.

10 W. Erben, Die Kaiser-und Königsurkunden des Mittelalters in Deutschland, Frankreich und Italien, Munich 1907, 146-147; I. H. Garipzanov, The Symbolic Language of Authority in the Carolingian World (c. 751-877), Leiden-Brill, 2008, 167-168; isti, Metamorphoses of the Early Medieval signum of a Ruler in the Carolingian World, Early Medieval Europe, Vol. 15 (2006), 419-464, 428.

11 P. Grierson, M. Blackburn, Medieval European Coinage: With a Catalogue of the Coins in the Fitzwilliam Museum, Cambridge, vol. 1: The Early Middle Ages(5th-10th centuries), Cambridge 1986, 471, PI. 19, no. 388. 
си монограм Меровинга била је укључење владарске титуле - rex, поред слова владаревог имена, у формирање владарског знака. ${ }^{12}$ Ова промена дошла је као реакција на широку употребу персоналног монограма међу припадницима племства и цркве, као и појава урбаног монограма као обележја градског новца који је кован не само у држави Меровинга, већ на новцу италијанских и шпанских градова. Први урбани монограм понео је бакарни новац града Равене кован између 536. и 554. године, означавајући име градске ковнице. ${ }^{13}$ Тиме је монограм престао да буде ексклузивни знак владарског ауторитета, што је представљао у VI и раном VII веку.

Од Меровинга, традицију употребе монограма наследиће Каролинзи, па монограм затвореног типа носи већ новац Пипина Малог, искован 754/5, начињен од слова R P или RxP (Rex Pippinus) и слова R F (Rex Francorum). ${ }^{14}$ Међутим, поновно чврсто везивање монограма за владара и државну власт, десиће се тек увођењем монограма у облику крста на западни новац и повеље. Као signum владара, крстасти монограм се први пут среће 769. године, прво у повељама и на печатима Карла Великог, а потом 793/4. године и на његовом новцу. Монограм су чинила слова Карловог имена K A R L O V S „закачена“ за кракове крста. ${ }^{15}$ Монограм у облику крста ушао је у употребу код Каролинга под утицајем италијанског новчарства, био је чест на новцу кованом у западном Медитерану, а обележје је и папског новца кованог у Риму. ${ }^{16}$ У време владавине Карла Великог, употреба монограма била је резервисана искључиво за краља, док су остали чланови владарске породице користили крст као потпис. ${ }^{17}$ Крстасти монограм, као графички знак владарског ауторитета задржеће се код Каролинга током IX века.

12 I. Garipzanov, The Symbolic Language of Authority, 168; isti, Metamorphoses of the Early Medieval signum, 428.

13 I. Garipzanov, The Symbolic Language of Authority, 168; isti, Metamorphoses of the Early Medieval signum, 428.

14 P. Grierson, M. Blackburn, Medieval European Coinage, 520-523, PI. 33; I. Garipzanov, The Symbolic Language of Authority, 171; isti, Metamorphoses of the Early Medieval signum, 431. . Grierson, M. Blackburn, Medieval European Coinage, 524, PI. 34, no. 741-747, 532555, PI. 37-45; P. Grierson, The Coins of Medieval Europe, London 1991, 35, no. 78; I. Garipzanov, The Symbolic Language of Authority, 172; isti, Metamorphoses of the Early Medieval signum, 431.

16 P. Grierson, M. Blackburn, Medieval European Coinage, 564-571, PI. 48-49.

17 I. Garipzanov, The Symbolic Language of Authority, 181-182; isti, Metamorphoses of the Early Medieval signum, 439-440. 
Током читавог средњег века монограм је међу друштвеном елитом био графички знак par excellence коришћен да се њиме укаже на позицију и углед у друштву. До XII века присутан је у новчарству Запада, заједно са епиграфским натписом на реверсу, када га потискују хералдичке представе и све чешћа употреба владарских иницијала, најчешће почетног слова имена приказаног испод круне на аверсу. Ови „крунисани“ краљевски иницијали постају чести у западном новчарству XIV и XV столећа. ${ }^{18}$ Међутим, баш у овом периоду, монограм постаје поново популаран у Византији. У време Палеолога, у византијском новчарству појављује се нови тип монограма који, за разлику од оног коришћеног у претходном периоду, укључује и презиме владара. Осмишљен у време Михаила VIII Палеолога, нови тип монограма први пут је приказан на новцу Андроника II, формиран од слова П, А, Л и Г, најистакнутијих слова презимена ПАЛАІОЛОГОС. ${ }^{19}$ Монограм носи новац који кују цареви Андроник II, Андроник II и Михаило IX те Андроник III. Најчешће је приказан на аверсној страни новца, док је на реверсу представа владара. ${ }^{20}$

Осим на византијском новцу, у овом периоду употреба монограма честа је и на печетима, у архитектури, скулптури, у минијатурама, на одећи, накиту итд. У Манастиру Христа Хоре (Кахрије џамија), на портретима неких од чланова из династије Палеолога, на њиховој одежди, приказани су кружни медаљони са монограмима. ${ }^{21}$ Исти мотив носи и хаљина пронађена у једном од гробова у манастиру, за коју се претпоставља да припада кћерки Михаила VIII, Ирини Раулиној Палеологиној, умрлој 1332. године, 22 а у Гротаферати се чува

18 P. Grierson, The Coins of Medieval Europe, 116, 130, no. 307, 153-154, no. 349-350, 168, 171, 193, no. 423, 209.

19 P. Grierson, Catalogue of the Byzantine Coins in the Dumbarton Oaks Collection and in the Whittemore Collection, Vol. 5, Pt. 1, Michael VIII to Constantine XI (1258-1453), Washington 1999, 92-93.

20 P. Grierson, Catalogue of the Byzantine Coins in the Dumbarton Oaks Collection and in the Whittemore Collection, Vol. 5, Pt. 2, Michael VIII to Constantine XI (1258-1453), Catalogue, Concordances and Indexes, Washington 1999, PI. 35, no. 591-592, PI. 38, no. 661-670, PI. 40, no. 701-704, PI. 43, no. 760-762 i dr.

21 P. A. Underwood, The Kariye Djami, Vol. I, Historical Introduction and Description of the Mosaics and Frescoes, New York 1966, 284-286, 289-291, PI. 540-541, 546-547.

22 P. A. Underwood, n. d., 284-286, PI. 541; R. Ousterhout, Byzantium between East and West and the Origins of Heraldry, in: Byzantine Art: Recent Studies, C. Hourihane (ed.), Tempe-Ariz 2009, 153-157, 165-166, fig. 13. 
тканина чија је површина украшена монограмом Палеолога и двоглавим орловима. ${ }^{23}$

Сматра се да монограм који се у овом периоду јавља у Византији треба посматрати као неку врсту амблема, владарског симбола који настаје као византијски одговор на западну хералдику, која је од XII века снажно присутна у простору Медитерана. У исто време се наглашава да не треба занемарити ни исламски утицај, пре свега селџучку амблематику и употребу тугре, личног и династичког монограма исламских владара, која има своје паралеле са византијским монограмом. ${ }^{24}$ У време Палеолога, када хералдика са Запада снажно продире међу византијску елиту, монограм, комбинован са хералдичким амблемима често се среће на гробницама византијског племства. ${ }^{25}$ Судећи по употреби монограма у Визанитији у овом периоду, различити језици моћи друштвених елита са Истока и Запада у раздобљу између XII и XV века мешали су се и уливали један у други, насупрот свим разликама.

Попут Византије, и средњовековна Србија била је друштво у коме су се укрштали и спајали различити културни утицаји, уобличавајући, између осталог, и изглед српског средњовековног новца. Први монограм на нашим просторима среће се у сфрагистици, на печату великог хумског кнеза Андрије, сачуван на повељи издатој Дубровнику, нешто пре 1235. године. ${ }^{26}$ Ради се о монограму у облику крста који настаје под утицајем Византије. Појава монограма бележи се потом тек у другој половини XIV века, у српском новчарству, када је реверс једне емисије динара Вука Бранковића понео монограм ВЛК, кога су чинила слова Вуковог имена. Аверс овог новца носи представу Христа, под легендом IC-XC. ${ }^{27}$

Слику новца обласних господара, којима је припадао и Вук Бранковић, који се кује након распада Српског царства у областима локалних властодржаца, у овом периоду чиниле су владарске представе, епиграфски натписи и хералдичке представе смештене махом на реверсну страну, те представа Христа која је обележавала аверс

23 J. Ebersolt, Les arts somptuaires de Byzance, Étude sur l'art impérial de Constantinople, Paris 1923, 52.

24 S. Redford, Byzantium and the Islamic World, 1261-1557, in: Byzantium: Faith and Power (1261-1557), H. C. Evans (ed.), New York 2013, 388-396; R. Ousterhout, n. d., 167.

R. Ousterhout, n. d., 165.

P. Anđelić, Srednjovjekovni pečati iz Bosne i Hercegovine, Sarajevo 1970, 58-59, br. 30.

В. Иванишевић, Новчарство средњовековне Србије, Београд 2001, 280, бр. 31.15. 
новца. ${ }^{28}$ Овај репертоар представа био је наслеђен из периода царства, а појава монограма била је иновација која се, судећи по новцу Византије, надовезала на хералдичке представе које су у српску средину дошле са Запада.

Као и на Западу, хералдика је у српској средини била повезана са витештвом, а ангажовање страних витезова најамника у војсци српских владара био је један од путева прихватања и укорењивања хералдичких обичаја у српском друштву. Стране витезове у својим трупама имали су већ краљеви Милутин и Стефан Дечански, ${ }^{29}$ а у страним изворима се у овом периоду помиње први грб српског владара, али и грб једног великаша, ћесара Гргура. Наиме, у инвентару цркве Светог Николе у Барију, на предметима који су поклонили краљеви Милутин или Дечански, помиње се краљев грб (arma dicti regis), а на кандилу које је цркви приложио ћесар Гргур, уз његово име стајао је и његов грб (arma ipsius cesaris). ${ }^{30}$ У периоду владавине краља и цара Душана, међу српским трупама, али и у личној царевој служби налазе се немачки плаћеници на челу са витезом Палманом. Овај витез је од 1333. до цареве смрт 1355. био заповедник Душанове телесне гарде. ${ }^{31}$ У овом периоду фрагментари грб владара, шлем са челенком, ${ }^{32}$ а потом и потпуни грб,, биће приказани на српским динарима. Фраментарни или потпуни хералдички грбови, али и хералдички амблеми, као обележја владарских кућа, убрзо ће потом под

28 Исто, 147, 155-157, 266-284; М. Одак Михаиловић, Политичка идеологија новца: развој и поруке српских средњовековних ковања, у: Византијско наслеђе и српска уметност І. Процеси византинизације и српска археологија, Весна Бикић (ур.), Београд 2016, 143-151, 148.

29 К. Јиречек, Историја Срба, књ. II, Београд 1978, 112-114; С. Ћирковић, Почтени витез Прибислав Вукотић, Зборник Филозофског факултета у Београду X-1 (1968), 259276, 275; A. Veselinović, Vojska u srednjovekovnoj Srbiji, Vojnoistorijski glasnik 1-2 (1994), 385-422, 408-409; С. Шаркић, Правни положај странаца у средњовековној Србији, Зборник радова Правног факултета у Новом Саду 3 (2011), 53-67, 63-64.

30 С. Ћирковић, Допуне и објашњења, у: С. Новаковић, Историја и традиција: изабрани радови, Београд 1982, 436-478, 463-456, нап. 31, 32.

31 К. Јиречек, Н. Д., 111; С. Ћирковић, Н. Д., 275; А. Veselinović, n. d., 410; М. Ј. Динић, О витезу Палману, у: Из српске историје средњега века, С. Ћирковић, В. Ђокић (прир.), Београд 2003, 447-455; В. Иванишевић, Развој хералдике у средњовековној Србији, ЗРВИ XLI (2004), 213-234, 217; С. Шаркић, н. д., 65.

32 В. Иванишевић, Новчарство средњовековне Србије, 120, 244-245, бр. 6.4.2-6.5.2, 66-6.7, 247, 6р. 6.12.1-6.15.

33 Исто, 245, бр. 6.5.3. 
утицајем двора прихватити чланови српског племства, вршиоци високих државних и дворских служби. ${ }^{34}$ Њихово уздизање у самосталне господаре територија разрушеног царства, доводи њихове грбове и амблеме на новац који кују, какав је случај и са новцем Вука Бранковића.

Вук Бранковић потиче из породице са великом племићком традицијом, чији чланови су имали дуготрајну службу при двору немањићких владара. Његов деда Младен прво се помиње са титулом жупана за време краља Милутина, да би у служби краља Стефана Дечанског титулу жупана заменио титулом војводе, са којом је обављао дужности војсковође, што му је обезбеђивало високо место у рангу властеле. ${ }^{35}$ Његов син, Бранко Мледеновић носио је титулу севастократора, уз коју су ишли значајни властеоски поседи и улога намесника града Охрида. Севастократорска титула, према византијским обичајима, додељивана је истакнутој властели са којом је владарска породица могла бити у родбинским односима, ${ }^{36}$ што га сврстава међу најзначајније племиће цара Уроша, и отвара могућност да су Бранковићи могли бити у некаквим родбинским везама са Немањићима. О овој вези посредно сведочи свилени појас са извезеним именом Бранко, који се приписује Бранку Младеновићу, на којем је представљен фрагментарни грб - кабласти шлем са челенком израстајућег лава, ${ }^{37}$ а хералдички лав у српској средини први пут

34 Уп. Г. Острогорски, Серска област после Душанове смрт, Београд 1965, 88-90; М. Ћоровић-Љубинковић, Представа грбова на прстењу и другим предметима материјалне културе у средњовековној Србији, у: О кнезу Лазару, И. Божић, В. Ј. Ђурић (ур.), Београд 1975, 171-182; Ђ. Јанковић, Нека запажања о властеоским шлемовим XIV и XV века, Зборник Филозофског факултета у Београду XVI (1989), 147-162, 148-149; В. Иванишевић, Развој хералдике у средњовековној Србији, 218220, 222, 226-227; Д. М. Ацовић, Хералдика и Срби, Београд 2008, 198, $204-207$.

Р. Михаљчић, Крај Српског царства, Сабрана дела I, Београд 2001, 141-142; М. Благојевић, Државна управа у српским средњовековним земљама, Београд 1997, 44, 46; М. Спремић, Бранковићи у историји и предању, у: Прекинут успон: српске земље у позном средњем веку, Београд 2005, 329-344, 330; М. Шуица, Вук Бранковић: славни и велможни господин, Београд 2014, 21-23.

36 Б. Ферјанчић, Севастократори у Византији, ЗРВИ 11 (1968), 141-190; Р. Михаљчић, н. д., 254; Р. Михаљчић, И. Шпадијер, Слово браће Бранковића манастиру Хиландару, Стари српски архив, књ. 6 (2007), 151-166, 156; М. Шуица, н. д., 30-31.

37 С. Новаковић, Хералдички обичаји у Срба у примени и књижевности, у: Историја и традиција: изабрани радови, С. Ђирковић (прир.), Београд 1982, 293-436, 361; H. Granger-Taylor, Z. Gavrilović, Embroidered Belt or Border, in: Byzantium. Treasures of Byzantine Art and Culture from British Collections (Cat. Nr. 225), London 1994, 208-211; B. Иванишевић, Развој хералдике, 223; Д. М. Ацовић, н. Д., 169. 
се помиње на малом типару цара Уроша из 1366. године, који дубровачки канцелар описује као sigillo cum figura leonis. ${ }^{38}$ Лав ће постати хералдички амблем породице Бранковић и обележаваће њихов новац и печате.

Пропашћу српског царства и недостатком централне власти нестало је и репрезентативних титула и звања, па је Вук Бранковић носио титулу господин која је у овом периоду носила сву тежину владарског достојанства. ${ }^{39}$ Као самосталан владар владао је снажном државом на простору Косова и Метохије, Полимља и Санџака, а у саставу његове области били су градови Призрен, Приштина и Скопље. ${ }^{40}$ Уз кнеза Лазара, чији је био зет, Вук Бранковић био је један од најмоћнијих обласних господара у другој половини XIV века, а један од показатеља његове моћи било је и ковање сопственог новца, који је емитован у великом броју емисија. ${ }^{41}$

Новац је одувек био показатељ културне климе једног друштва, али у њему је остављен запис и о личности самог владара који га је емитовао. Новац Вука Бранковића, као и новац осталих обласних господара, показује продор утицаја источних и западних цивилизација на српском тлу, који се огледа у представама и натписима које носи. Ако погледамо начин на који је Вук Бранковић себе представио на динарима које кује, наћи ћемо слику владара уобличену у византијском стилу, у представи господина који стоји одевен у царском орнату, додуше без круне, и држи инсигније власти у рукама, скиптар са крстом, али и заставу, ${ }^{42}$ а осим владарске представе, византијског порекла је био и вишередни ћирилички натпис „У Христа Бога благоверни Вук" који ће понети једна емисија Вуковог динара. ${ }^{43}$ Западне утицаје срећемо у представи владара у властеоској хаљини са појасом који седи на престолу, ${ }^{44}$ али и у хералдичким представама које носи његов

38 G. Čremošnik, Studije za srednjovjekovnu diplomatiku i sigilografiju južnih Slavena, Sarajevo 1976, 133; С. Марјановић-Душанић, Владарске инсигније и државна симболика у Србији од XIII do XV века, Београд 1994, 109.

39 Р. Михаљчић, Господин, у: Владарске титуле обласних господара, Сабрана дела IV, Београд 2001, 107; М. Спремић, н. д., 329-330; М. Шуица, Н. д., 71.

40 М. Динић, Област Бранковића, Прилози за књижевност, језик, историју и фолклор, књ. XXVI, св. 1-2 (1960), 5-29, 9-12; М. Спремић, н. д., 330; М. Шуица, н. д., 70. В. Иванишевић, Новчарство средњовековне Србије, 168-169. Исто, 169, 279, 6р. 31.6.1-31.7.

Исто, 169, 278, бр. 31.2 .

Исто, 169, 280, 6р. 31.17. 
новац: фрагментарном грбу - шлему са челенком, ${ }^{45}$ односно шлему са челенком поред кога је представљен штит, ${ }^{46}$ представи штита која је на једној емисији његових динара уметнута испод натписа „Вуков динар“, ${ }^{47}$ али већ на следећој емисији приказана самостално у пољу реверса, ${ }^{48}$ те хералдичком лаву, амблему куће Бранковића, који носи реверс једне емисија његовог новца. ${ }^{49}$ Ту је и необична представа неоседланог коња без јахача, ${ }^{50}$ ратничке инсигније у српској средини, јединствена у српском средњовековном новчарству.

Између ових слика и речи које је Вук Бранковић изабрао да себе представи на свом новцу, креирајући путеве комуникације са онима међу којима је новац циркулисао, монограм је постао веза која је стала између слике и натписа, између византијског и западног. И док су у средњем веку грбови и хералдички амблеми били знамење владарске и племићке куће које се наслеђивало, монограм са словима његовог имана истакнут је овде као лични, индивидуални амблем, који је истицао личност самога Вука - владара, племића и ратника, како су га описивале представе на његовом новцу. Био је ово увод у потоњу ритерску идеју владавине која ће се развити у периоду српске Деспотовине, снажно окренуте Западу, у којој ће идентитет личности владара бити истицан и раздвајан од династичко-државне компоненте. ${ }^{51}$

У периоду Деспотовине монограм носи реверс једне емисије динара деспота Стефана Лазаревића, формиран од слова ДТПС, унутар $\varepsilon-\omega$, горе лево S. Аверсна страна новца носи представу Христа у мандорли, уз легенду IC-XC. ${ }^{52}$ Нешто више је заступљен у новчарству деспота Ђурђа Бранковића, где га носе три емисије динара. На аверсу једне емисије, унутар кружне легенде +ГNЬ ДЄСПОТЬ Б, формиран је монограм од слова ГЮРЬГЬ, док је на реверсу лав passant. ${ }^{53}$ Монограм на аверсу и реверсу носе две емисије деспотових динара, на аверсу је формиран од слова ДЕСПОТь и приказан самостално

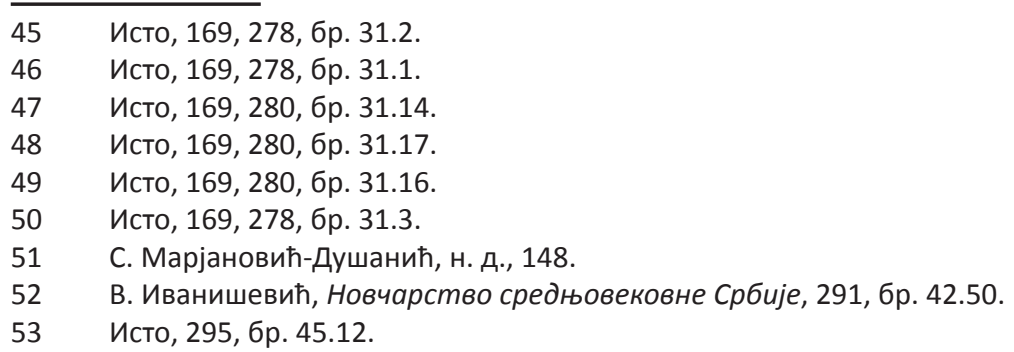


у пољу, ${ }^{54}$ односно постављен изнад главе владара, ${ }^{55}$ а на реверсу је формиран од слова ГЮРЬГЬ.

За разлику од монограма Вука Бранковића, монограм српских деспота поред слова имена укључује и титулу владара, што је свакако била последица снажне циркулације турског новца на простору српске државе у периоду Деспотовине. Од почетка XV века, турске сребрне акче или аспре, заједно са српским новцем, присутне су у свакодневним трансакцијама у Србији. ${ }^{56}$ Калиграфски исписана слова у вишередном натпису била су једини мотив који срећемо на турским аспрама и мангурама, а у време владавине Сулејмана Челебија, почетком XV века, на турском новцу ће се први пут наћи тугра - султанов монограм, који се састоји од његовог имена и титуле. ${ }^{57}$ Поред владарских представа западног типа, хералдичких представа те натписа који обележавају српски новац у овом периоду, монограм као знак владарског ауторитета био је нека врста српског одговора на турски новац и његову иконографију, која се наметала српском друштву. Као у Византији, исламски и хришћански утицаји стопили су се у српској средини на нов начин у овом старом симболу власти и престижа, користећи његову изражајност у тадашњем свету комуникација.

После владарског двора, употреба монограма у средњовековној Србији веома брзо продрла је међу друштвене елите, о чему сведочи пракса да се монограм ставља у средину натписа на печатном прстењу, а овакво прстење било је посебно популарно међу босанским великашима крајем XIV и почетком XV века. ${ }^{58}$

54 Исто, 298, 6р. 45.33 .

55 Исто, 298, бр. 45.34.

56 М. Динић, Област Бранковића, 26-27; Д. Ковачевић-Којић, Приштина у средњем вијеку, Историјски часопис XXII (1975), 45-74, 66-69; М. Динић, За историју рударства у средњовековној Србији и Босни, у: Из српске историје средњега века, С. Ћирковић, В. Ђокић (прир.), Београд 2003, 455-669, 641-643; В. Иванишевић, В. Радић, Ковница српског средњовековног новца у Новом Брду, у: Ново Брдо, В. Јовановић ...(и др.), Београд 2004, 222-247, 234.

57 A. Damali, Osmanli Sikkeleri Tarihi/History of Otoman Coins, Vol. 1, Istambul 2010, 171, 4AG1-805.

58 P. Anđelić, n. d., 64-65, br. 35-36, 69-70, br. 42-43, 70-72, br. 44-46, 73-75, br. 48-51, 77, br. 54, 78-82, br. 56, 60-61. 


\section{Marina Odak Mihailović}

\section{THE MONOGRAM-THE GRAPHIC SIGN OF SOVEREIGN AUTHORITY ON SERBIAN MEDIEVAL COINS}

\section{Summary}

The monogram on the dinars issued by Vuk Branković, and Despots Stefan Lazarević and Đurađ Branković, emerged as the result of the acceptance of the concepts of chivalric and courtly culture that had reached Serbia from the West, and on the other hand, of the adjustment of Serbian coinage to the iconography on Ottoman coins that had already been widely available on Serbian market squares of the $15^{\text {th }}$ century. The monogram, used on Serbian coins as the ruler's individual emblem, was the symbol with which the ruler's authority was made manifest firstly by a local ruler and later by Serbian despots. Similarly to the coat-of-arms or the heraldic emblem, which served as reminders of the noble tradition of the ruling family, the monogram was a succinct embodiment of the ruler himself, replacing his portrait on the coin. A combination of the letters of the ruler's name, it became more personal; unlike images but similar to epigraphic inscriptions, it was addressed to those members of the society who knew how to read its message. The preference of the ruler to be represented not only by the image but also by letters shows, among other aspects, the importance attached to literacy and the written word as an indication of the social status in the Serbian medieval society, just as it was in the Byzantium and the medieval West.

Key words: Middle Ages, coins, seals, monogram, sovereign's insignia, sovereign ideology. 